\title{
Black Consciousness, Agenda Setting and Public Policy in South Africa
}

\author{
Sechaba Khoapa ${ }^{1,2}$ \\ ${ }^{1}$ Department of African Studies, Howard University, Washington, USA \\ ${ }^{2}$ Department of History and Political Science, Florida A\&M University, Tallahassee, USA
}

Email address:

skhoapa@hotmail.com

To cite this article:

Sechaba Khoapa. Black Consciousness, Agenda Setting and Public Policy in South Africa. Social Sciences. Vol. 7, No. 4, 2018 , pp. $161-164$. doi: $10.11648 /$ j.ss.20180704.12

Received: June 20, 2018; Accepted: July 5, 2018; Published: July 27, 2018

\begin{abstract}
The central focus of this textual analysis and research is to provide an overview and theoretical explanation of how public policy in South Africa has been chosen for inclusion based on the agenda setting practices of local media and government. The suggested notion behind the agenda setting practices is that they are instituted at the social, political and economic marginalization of the grass roots population which in fact comprises nearly 65 percent of the South African population. In addition, there is an examination of the Black Consciousness ideology of Stephen Bantu Biko and its historical and fundamental foundations in an attempt to address the social, political and economic empowerment of the grass roots population in South Africa. By offering Black Consciousness as development policy through a specific public and political agenda; economic and political equality in South Africa can be achieved.
\end{abstract}

Keywords: Black Consciousness, Critical Discourse, Agenda Setting, Poverty and Inequality, Public Policy

\section{Introduction}

In established constitutional democracies such as the United States, government powers are generally exercised within a framework of rules, a constitution that defines the duties and functions are a government institutions, the rights of citizens and limitations on the powers of the government.[1] The result of government institutions functioning in a manner where subjects and certain members of society through the public and political policy agenda are unanticipated and unevenly distributed in allocation of resources. The agenda inherently protects the interests of the dominant group. In the case of South Africa, the dominant group is not represented in population numbers; but in control of economic resources.

According to Kalu [1], issues in public policy agenda are largely dictated by a political process model based on the issues, the actors, their interests, and resources they have and are willing to commit to securing their preferred outcome. Kalu further adds, "The dynamic process of social interactions in pursuit of a particular good therefore leads to unanticipated outcomes with rewards for some and losses for others".

\section{Agenda Setting and Public Policy}

The process of agenda setting assumes that in the context of politics, defined as the redistribution of scarce economic resources on the basis of values, ideas, issues and actors compete with each other. According to Kalu, "what becomes an issue in the public policy agenda reflects the values and victory of government officials whose ideas or resources outweigh the opposition". Examining how the relationship between the governance and allocation of resources is designed, the actual process of agenda setting in policy decision making is outlined in the following stages: 1) agenda setting stage - whereby the competition for ideas and policies are shaped; 2) policy formulation stage - whereby issues of government decision makers or appropriately, the bureaucrats whose knowledge and expertise on the subject help shape issues on the agenda plate into an acceptable piece of legislation; 3) policy legitimization stage - whereby the legislative branch of government will support or reject the policy in ways consistent with promises made to relevant constituencies and their goals; and 4) implementation and feedback stage - whereby the policy process is perhaps the 
most important for decision makers and those who have been affected by the policy. In the case of South Africa, these processes presume the existence of a constitutional framework whereby the model is well understood and guides the actions in the participants in the decision making and implementation process. The gap in margin however in the South Africa is affecting a population that is not equipped with the civil legislative education to fairly bargain for the appropriate distribution of resources.

\section{Biko and Black Consciousness}

The Black Consciousness Movement started to develop during the late 1960s, and was led in part by Stephen Bantu Biko [2]. During this period, the African National Congress (ANC) had committed to an armed struggle through its military wing Umkhonto we Sizwe, but this small guerrilla army was neither able to seize and hold territory in South Africa nor to win significant concessions through its efforts. The ANC had been banned by the apartheid government, and although the famed Freedom Charter remained in circulation in spite of attempts to censor it, for many students the ANC had disappeared. As black people continued to struggle to find ways to gain ground against Apartheid, Biko and other Black Consciousness theorists began to concern themselves not only with political liberation but with the meaning of blackness itself.

Biko's understanding of these thinkers was further shaped through the lens of post-colonial thinkers such as Frantz Fanon and Paulo Friere [3]. Biko emphasized the concern for the existential struggle of the black person as a human being, dignified and proud of his/her blackness, despite the oppression of colonialism. The aim of this global movement of black thinkers was to restore black consciousness and African consciousness, which they felt had been suppressed under colonialism.

Another important component of psychological liberation was to embrace blackness by insisting that black people lead movements of black liberation. This meant rejecting the fervent non-racialism of the ANC in favor of asking whites to understand and support, but not to take leadership in the Black Consciousness Movement. A parallel can be seen in the United States, where student leaders of later phases and black nationalists such as Malcolm $\mathrm{X}$ rejected white participation in organizations that intended to build black power, more so identity. While the ANC viewed white participation in its struggle as part of enacting the non-racial future for which it was fighting, the Black Consciousness view was that even well-intentioned white people often reenacted the paternalism of the society in which they lived. This view held that in a profoundly racialized society, black people had to first liberate themselves and gain psychological, physical and political power for themselves before non-racial organizations could truly be non-racial.

In an interview in 1973 Biko explained, "In the 1960s, the African Congress had been banned, so the main realities we were confronted with were the power of the police and the leftist noises of the white liberals. Faced with these realities, we had to solve the question of how a new consciousness could take hold of the people." "The government controlled the schools. There was a low output from the schools as far as Black Consciousness was concerned. We knew we had to seek for participation among the intelligentsia. But we also knew that the intelligentsia tend to look upon the masses as tools to be manipulated by them, so the change of consciousness among graduates of the black universities that we sought focused on an identification of intellectuals with the needs of the black community". The relationship between the intelligentsia as Biko refers is the same relationship between the marginalized groups at that time and continues to orchestrate the same actions among a democratic South Africa; but hidden in the political discourse that grass roots populations are deprived of.

\section{Critical Discourse Analysis}

Critical discourse analysis (CDA) is an approach of critical theory where by language is understood as an instrument to maintain and perpetuate power in a macro-society. The ability for power to be maintained is also achieved by the manufactured consent of the micro-society, what Antonio Gramsci defined as hegemony. [4] What CDA tries to achieve in the same manner that critical theory aims to achieve is emancipation and social change. The way in which CDA seeks this is in exposing the agency in language which is not always implicit in micro-level understanding of discourse.

CDA is unique as a perspective on language as a dynamic in modern forms of power and social control primarily because it challenges those forms of power and social control. In any language there is a systematic and consented understanding to its meaning as understood within a social macro or microcosm. Often within that meaning there is a basis of knowledge, all that constitutes content of consciousness, truth or what is perceived to be truth. Critical discourse analysis ultimately suggests that there is no absolute truth; therefore an interpretation is based on individual epistemology, ontology and axiology within that particular social order. The other aspects of CDA further include power, the relational dialectic between the have's and have not's. Rhetoric focuses on individual use more so than a collective. CDA steps in to uncover the intended meaning of language use or agency with which it is prescribing.

All language is used to maintain a particular social order in order to maintain a particular "status quo," and that status quo inherently seeks to maintain control of it self in order to maintain its importance. This is where we discuss the assertion of power because in order to maintain a system of beliefs that one culture prescribes, it is necessary to suppress the "other." Looking at the linguistic analysis of X and Y, we begin to describe how the assertion of power is implemented when we construct the notion that $\mathrm{X}$ is $\mathrm{Y}$. Having the variable $\mathrm{X}$ with the $\mathrm{Y}$ as a receiver of action, it becomes clear. Leslie Stevenson posed the question, "If someone says "Human beings are naturally X,' or that we should all be X, or what" 
[5]. He further suggested that, "Maybe what is meant is 'Whenever human beings are not $X$, they suffer consequences $\mathrm{Y}$ ". "Here we have both a factual generalization and implicit value-judgement about the understandability of Y". This is puts forth a statement, "You are not smart." In this statement we can identify the variables, subject, verb and direct object similar to the equation $\mathrm{X}$ is $\mathrm{Y}$, now in this particular statement the subject $\mathrm{X}$ is "You" and the direct object $\mathrm{Y}$ is "smart." The verb in this case "is" the participial of the verb "To be" serves as the word of assertion despite the negation of the word "Not"." If X is Y then the negation asserts that "You" are smart. The agency then becomes apparent, but hidden within the actual formation of the language sentence in order to exclude.

Now, exclusion in a post-modernist framework does not exclusively allow for the out-right demonstration of power in a physical exchange, but rather from a philosophical and ideological exchange that is achieved through discourse. One goal of discourse is to disguise the "agent" burying its meaning in the form of the language. This occurrence is very prevalent in the discourse of law and lawyers whereby the simple understanding and use of legal grammar excludes those who do not practice it. Power is maintained by the consented subordination of the civilian and the perceived fear of "reward and punishment".

CDA directly identifies the inequality and seeks to confront it rather than be complicit of it. CDA uses the discourse of inequality to re-establish or address the concerns of the apparent marginalized group. Using grammar such as the system, the policy or procedure, it can believe that the nominalization and passivization of these words has an actual location. Who does "they," "we," or even "them" actually refer to? Within that language, what is assumed and what is buried? "Our" (those that are marginalized) understanding of this language places "our" interpretation in a location that empowers "our" agenda to serve "our" needs and concerns [5]. Critical- looks to position one with those facing social inequality and injustice and Discourse- explains the language-based representation of some aspect of social life from a part-perspective. In my own understanding, Analysisseeks to place this relationship between the two in a modality of thought and understanding that is pragmatic to the balance of power between different groups which inherently are pursuing soverenty within a multi-ethnic, cultural and political world towards achieving empowerment-the ability to function within the status quo and ability to change the status quo.

\section{Policy and Decision Making in South Africa}

The public policy process can traditionally be divided into the following stages: the agenda setting stage in which a problem is recognized and defined, after this stage possible policy alternatives are identified, the options are evaluated; there is a policy decision, implementation of the selected policy option and after certain time, evaluation of the program. Although these stages help in order to analyze the policy process, in reality the stages are not well defined stages, rather, the stages can overlap and influence the outcome in other stages. This research focuses on Black Consciousness and the Agenda Setting Stage, the stage in which possible policy options are considered, and the policy decision stage. The decision making process itself relates to the choice between the different alternatives for governmental action.

Critical to this research is the theory of Molefi Asante [6] and Afrocentricity, describing the elements that comprised the fundamental base of Black Consciousness both in theory and in practice. These different processes address steams of problems, policies and politics. In order for public policy to come about the three different streams have to meet. When this happens, there are enough policymakers who are convinced that a certain problem should be addressed by a certain policy alternative. John Kingdon [7] who explains policy steam theories describes "certain factors within the streams that can either work as an impetus or as a constraint.," These factors help explain the disconnect between current public policy and marginalized groups to the appropriation of resources in South Africa.

\section{Discussion}

An agenda is a list of issues or problems to which people are paying serious attention to; there are different kinds of agendas, like media agendas or personal agendas. The governmental agenda is the list of topics or problems that governmental officials and people who are closely related to these officials are paying serious attention to. Within this agenda there are some subjects which are up for decision; these issues are placed on the decision agenda.

Similarly there is also a list of policy alternatives to which governmental officials and people related to these officials are paying attention to. Many people are trying to influence what issues and alternatives are being considered by governmental officials, but the outcome of the agenda setting process is far from predictable. Throughout the policy process different processes and participants are able to push or constrain a problem or alternative on the agenda.

In an article written by Nadine Schnek [8], she explains that "the cohesion between different participants is further defined by Sabatier's Advocacy Coalition [9], this theory focuses more on networks that participants form in order to more successfully pursue their objectives. Sabatier distinguishes policy subsystems as units of analysis rather than specific governmental institutions". Some of the actors share critical aspects of their belief system which is reflected by common believes and objectives, they will form a coalition within the political subsystem to pursue their common objectives. Within the constraints of government, appropriate allocation of resources to marginalized groups would greatly influence public finance in South Africa. Ultimately the goal is to level the playing field in order to 
have the equal social, political and economic representation of a truly democratic and free South Africa. Public policy is a critical component in any country or nation state and South Africa is no exception through its transformation [10].

\section{Conclusion}

A policy window is needed in which the streams are coupled and policy is made. An open policy window stands for a change on the agenda which could be an opportunity for people who want to push their proposal or problem higher on the agenda. These policy windows are usually created by occurrences in the problem or political stream. A policy window can be opened by a pressing problem or a change in the political stream, for instance a change in administration, change in governmental officials or the national mood. If a problem comes up through focusing events like disasters and crises, the public expects the government to take action, if governmental officials agree they have to address the issue, they will turn to the policy stream to seek a solution.

A change in the national mood or the administration also changes the composition of issues on the agenda, giving way to proposals which are in line with the issues that have risen on the agenda. Crucial to this process is the policy entrepreneur, a person who is willing to invest his/her resources to push for a policy alternative of solution. At the opening of a policy window the policy entrepreneur has to be ready to come forward with a solution to the problem or a policy alternative that is in line with the issues that are high on the agenda after events in the political stream.

\section{References}

[1] Kalu, K. (2004). Agenda setting and public policy in Africa. Aldershot and Burlington, 68-69.

[2] Biko, S. (1973). I write what I like. Interview. The University of Chicago Press.

[3] Van Sertima, I. (1989). Great African thinkers: Cheikh Anat Diop, vol. 1. Transition Books, UK.

[4] Gramsci, A. (No date). Hegemony-manufactured consent. Theory.

[5] Stevenson, L. (1987). Seven theories of human nature. Oxford University Press, 18-19.

[6] Asante, M. (1988). Afrocentricity. Africa World Press.

[7] Kingdon, J. (2003). Agendas, alternatives, and public policies. Longman, New York.

[8] Schnek, N. (2007). Political decision making and agenda setting in South Africa. USBIG Paper.

[9] Sabatier, A. (1993). Policy change and learning: an advocacy coalition approach. Westview Press.

[10] SA News24. (2015). A critical analysis on South African public policy formulation: The democratic inclusiveness of stat. (online). https://www.news24.com/MyNews24/a-criticalanalysis-on-south-african-public-policy-formulation-thedemocratic-inclusiveness-of-stat-2-0151202 